Volume 10, Nomer 01, 2020

\title{
Community-Based Healthy Lifestyle Intervention Program (Co-HELP) Modi- fication Meningkatkan Kualitas Hidup Pasien DM
}

\author{
Syulce Luselya Tubalawony ${ }^{1}$, Fransiska Dewi Prabawati ${ }^{2}$ \\ ${ }^{1,2}$ Program Studi Keperawatan Program Magister,STIK Sint Carolus \\ Email : syulce23@gmail.com ${ }^{1}$,deprab24@yahoo.com²
}

\begin{abstract}
Abstrak
Pendahuluan: Era modern yang terjadi menyebabkan perubahan gaya hidup seperti tingginya pola konsumsi fast food dan kurangnya aktivitas fisik menyebabkan peningkatan penyakit kronis salah satunya Diabetes Melitus (DM). Tujuan penelitian ini adalah untuk menganalisis efektivitas Community-Based Healthy Lifestyle Intervention Program (Co-HELP) Modification terhadap kualitas hidup, kadar gula darah puasa dan tekanan darah pasien DM.

Metode: Rancangan quasy experiment digunakan dengan melibatkan 76 responden yang terbagi atas 51 responden kelompok intervensi dan 25 responden kelompok kontrol yang dipilih dengan teknik purposive sampling. Kualitas Hidup responden diukur menggunakan kuesioner diabetes quality of life. Analisa hasil penelitian dengan uji Wilcoxon dan uji Mann-Whitney

Hasil: Mayoritas responden kategori dewasa madya, perempuan $(77,6 \%)$, lama menderita $\mathrm{DM}>5$ tahun $(67,1 \%)$, pekerjaan ringan $(82,9 \%)$. Setelah 6 minggu diberikan intervensi Co-HELP Modification didapatkan hasil menujukan ada perbedaan yang signifikan pada kualitas hidup ( $\mathrm{p}=0,000)$, kadar gula darah puasa $(\mathrm{p}=0,000)$, namun hasil uji untuk tekanan sistole dan tekanan diastole tidak ada perbedaan. Hasil uji regresi logistik ordinal menunjukkan bahwa intervensi Co-HELP Modification, umur, jenis kelamin, lama menderita/sakit DM dan pekerjaan secara simultan berpengaruh terhadap kualitas hidup $(\mathrm{p}=1,000)$, kadar gula darah puasa $(\mathrm{p}=0,975)$, tekanan sistole $(\mathrm{p}=1,000)$ dan tekanan diastole $(\mathrm{p}=0,315)$.

Kesimpulan :Penelitian ini merekomendasikan perlunya menerapkan Co-HELP Modification sebagai langkah mencegah komplikasi sehingga kualitas hidup pasien meningkat.
\end{abstract}

Kata Kunci: Co-HELP Modification; Diabetes Melitus; gula darah puasa: kualitas hidup; tekanan darah

\section{Pendahuluan}

Diabetes Melitus (DM) adalah isu global. World Heart Federation (WHF) menjelaskan DM merupakan penyakit mematikan kedua di

\begin{abstract}
Background: The modern era that occurs couses lifestyle changes such as hing consumption patterns of fast food and lock of physical activity couses an increase in cronic diseases, one pf them Diabetes Mellitus (DM). The purpose of this study was to analyze the effectiveness of community-based healthy lifestyle intervention program (Co-HELP) Modification in DM patients at the Waai Health Center, Ambon.

Methods: Quasy experiments were utilize. There were 76 respondents which chosen using purposive sampling techniques and divided into 2 groups where 51 respondents into intervention group and 25 respondents as control group. Quality of life was measured by DQOL questionnaire. Analysis of research results with the Wilcoxon and Mann-Whitney test

Results: It was revealed that majority of respondents on the elderly category, women (77.6\%), suffer from $D M>5$ years (67.1\%), light work (82.9\%). After 6 weeks of Co-HELP Modification, statistical test declared that there were significant differences in quality of life $(D Q O L)(p=0,000)$, fasting blood sugar $(F B S)$ levels $(p=0,000)$ pre-post intervention, however there were no significant difference for systole and diastole blood pressure. The logistical regression test revealed that Co-HELP Modification intervention, age, gender, long suffered from DM and occupation were significant impact to quality of life simultaneously $(p=1,000)$, blood glucose $(p=0,975), \operatorname{SBP}(p=1,000)$ and DBP $(p=0.315)$.

Conclusion: It is recommended to implement $\mathrm{Co}$ HELP Modification as a preventive aspect to prevent complication so that quality of life improves
\end{abstract}

Keywords: Blood pressure; Co-HELP Modification; Diabetes Melitus; fasting blood sugar; quality of life;

dunia yaitu sebanyak 17 miliar orang diikuti dengan kanker 8,2 miliar dan respiratory disease 4 miliar. $^{1}$ Indonesia berada pada posisi

Accepted: 07/03/20

Published:30/30/20 
ketujuh untuk prevalensi pasien DM tertinggi di dunia. ${ }^{2}$ Hasil Riset Kesehatan Dasar tahun 2018 menunjukkan terjadi peningkatan kasus DM dari tahun 2013 sampai 2018 yaitu sebanyak 6.9\% menjadi $8.5 \% .^{3}$

Puskesmas X merupakan puskesmas yang wilayah kerjanya mencakup 2 desa yaitu desa Waai dan desa Liang. Hasil wawancara dengan salah satu petugas kesehatan Puskesmas X (2019) menyampaikan jumlah pasien DM Puskesmas X mengalami peningkatan dari tahun ke tahun, data Januari sampai dengan Mei 2019 terdapat \pm 83 pasien terdiagnosis DM dan tahun 2018 terdapat 3 pasien meninggal karena penyakit DM. Menanggapi masalah yang terjadi, pihak Puskesmas $\mathrm{X}$ sudah mengambil satu langkah yang tepat yaitu dengan menyediakan program pengelolaan penyakit kronis (Prolanis) yang berjalan sejak April 2018. Namun kendala program tersebut yaitu penyampaian materi yang tidak teratur atau penyakit yang di sampaikan setiap minggu berbedabeda, sehingga peserta prolanis tidak mendapatkan satu pengetahuan yang utuh tentang satu jenis penyakit sebelum berlanjut ke pembahasan materi penyakit lainnya. Selain itu tidak tersedianya booklet untuk peserta dari setiap jenis penyakit yang di jadikan materi prolanis.

Penatalaksanaan dan pencegahan DM dapat dilakukan dengan mengadopsi gaya hidup sehat, seperti meningkatkan aktivitas fisik dan mengurangi morbiditas dan mortalitas pada pasien DM. ${ }^{2,4}$ Beberapa program DM yang terbukti berpengaruh memperbaiki kualitas hidup, kadar gula darah dan meningkatkan pemahaman tentang DM dengan memperbaiki gaya hidup pasien DM, yaitu Mediterranean lifestyle program (MLP), Lifestyle Intervention Program danDiabetes Self-Management Education and Support (DSME/S).

Program pendidikan DM yang diadopsi, harus relevan secara budaya di Indonesia, Model pendidikan yang diterapkan perlu mempertimbangkan karakteristik, latar belakang etnis dan budaya. ${ }^{5}$ Community-Based Healthy Lifestyle Intervention Program (Co-HELP) adalah salah satu program pendidikan DM dari Malaysia yang memiliki budaya dan karakteristik relevan sama dengan orang Indonesia. Implementasi Co-HELP mengombinasikan antar komponen pengetahuan, diet, aktivitas fisik dan satu komponen tambahan yaitu family and social support. Pada komponen diet, Co-HELP akan dimodifikasi sesuai dengan etnis masyarakat Maluku, hal ini didasarkan karena masyarakat Maluku memiliki makanan pokok dan banyaknya sumber daya alam dengan indeks glikemik yang rendah sehingga sangat baik untuk terapi diet pasien DM. Berdasarkan masalah diatas maka penyusun tertarik untuk melakukan penelitian tentang efektivitas Community-Based Healthy Lifestyle Intervention Program (Co-HELP) Modification terhadap kualitas hidup, kadar gula darah puasa dan tekanan darah pada pasien DM

\section{Metode}

Rancangan penelitian yang digunakan adalah quasy eksperimental. Pengambilan sampel penelitian menggunakan teknik purposive sampling, jumlah populasi dalam penelitian ini sebanyak 100 responden kemudian sampel dibagi 2 kelompok yaitu kelompok intervensi sebanyak $75 \%$ dan kelompok kontrol $25 \%$, namun dalam penelitian peneliti hanya dapat mengumpulkan pasien sebanyak 76 responden sampel dan dibagi 51 responden untuk kelompok intervensi dan 25 untuk kelompok kontrol. Penelitian ini dilakukan di wilayah kerja Puskesmas X, Maluku pada bulan April-Mei 2019.

Alat untuk mengukur kualitas hidup pasien DM adalah kuesioner Diabetes Quality of Life (DQOL) oleh Jeanny Rantung (2015) yang dikembangkan dari DCCT Research Group (1988). Hasil uji validitas pada 36 pernyataan DQOL dengan nilai $r$ alpha berada pada rentang nilai 0.044- 0.857 . Hasil uji reliabilitas kuesioner ini adalah $r$ alpha cronbach's 0.969 lebih besar dibandingkan dengan nilai $r$ tabel $(r=0.361)$, sehingga kuesioner kualitas hidup dinyatakan reliabel. ${ }^{6}$

Analisis yang digunakan pada penelitian adalah analisis univariate dengan analisis mean, dan standar deviasi, untuk variabel umur sedangkan analisis kategori untuk variabel jenis kelamin, lama menderita dan pekerjaan dijelaskan dengan nilai frekuensi dan persentase. Analisis bivariate menggunakan uji Wilcoxon dan uji Mann-Whitney, Analisis multivariate menggunakan uji regresi logistik ordinal. Penelitian ini telah lolos uji etik dari Tim Komisi Etik STIK Sint Carolus dengan nomor ; 03/KEPPKSTIKSC/III/2019

\section{Hasil}

Hasil penelitian menunjukkan rata-rata umur responden 56,88 tahun pada kelompok intervensi dan 54,96 tahun pada kelompok kontrol sehingga dapat di simpulkan bahwa kategori 
umur dewasa madya (40-60 Tahun) lebih berisiko terkena DM dibandingkan dengan kategori umur yang lain. Usia dewasa madya lebih bersiko terkena DM disebabkan karena. Proses penuaan yang terjadi juga berefek pada disfungsi sel $B$ pankreas dan intoleransi glukosa sehingga kurangnya produksi insulin yang menyebabkan terjadinya hiperglikemia.

Tabel 1. Karakteristik responden berdasarkan jenis kelamin, lama menderita DM, dan pekerjaan.

\begin{tabular}{lcclc}
\hline $\begin{array}{l}\text { Karakteristik } \\
\text { Responden }\end{array}$ & $\begin{array}{l}\text { Kelompok } \\
\text { Intervensi }\end{array}$ & \multicolumn{2}{l}{$\begin{array}{l}\text { Kelompok } \\
\text { Kontrol }\end{array}$} \\
\cline { 2 - 5 } & $\mathrm{n}$ & $\%$ & $\mathrm{n}$ & $\%$ \\
$\begin{array}{l}\text { Jenis Kelamin } \\
\begin{array}{l}\text { Laki-laki } \\
\text { Perempuan }\end{array}\end{array}$ & 10 & 19,6 & 7 & 28 \\
Lama Menderita & & 80,4 & 18 & 72 \\
DM & & & & \\
< 5 Tahun & 26 & 51 & 25 & 100 \\
5-10 Tahun & 22 & 43,1 & 0 & 0 \\
$>$ 10 Tahun & 3 & 5,9 & 0 & 0 \\
Pekerjaan & & & & \\
Ringan & 39 & 76,5 & 24 & 96 \\
Sedang & 3 & 5,9 & 0 & 0 \\
\hline
\end{tabular}

\begin{tabular}{lllll}
\hline Berat & 9 & 17,6 & 1 & 4 \\
\hline
\end{tabular}

Tabel 1 menunjukkan bahwa: Karakteristik jenis kelamin responden pada tabel di atas memperlihatkan bahwa pada kelompok intervensi dan kelompok kontrol jumlah responden perempuan lebih banyak dibandingkan dengan jumlah responden laki-laki yaitu masing-masing sebanyak $41(80,4 \%)$ dan 18 (72\%). Karakteristik lama menderita/sakit DM pada tabel di atas memperlihatkan bahwa pada kelompok intervensi dan kelompok kontrol lebih banyak responden yang menderita/ sakit DM selama kurang dari 5 tahun yaitu masing-masing sebanyak $26(51 \%)$ dan $25(100 \%)$. Seseorang yang sedang mengalami penyakit kronis dalam waktu yang lama akan mempengaruhi pengalaman dan pengetahuanindividu tersebut dalam pengobatan DM. ${ }^{17}$

Karakteristik pekerjaan pada tabel di atas memperlihatkan bahwa pada kelompok intervensi dan kelompok kontrol lebih banyak responden dengan status pekerjaan ringan (IRT, pegawai kantor, pegawai toko, guru dan ahli hukum) yaitu masing-masing sebanyak 39 $(76,5 \%)$ dan 24 (96\%).

Tabel 2. Analisa Bivariat Community-Based Healthy Lifestyle Intervention Program (Co-HELP)

\begin{tabular}{|c|c|c|c|c|c|c|c|c|c|c|}
\hline \multirow[t]{3}{*}{ Variabel } & \multicolumn{4}{|c|}{ Kelompok Intervensi } & \multicolumn{4}{|c|}{ Kelompok Kontrol } & \multirow{3}{*}{$\begin{array}{l}\text { Uji Wil- } \\
\text { coxon }\end{array}$} & \multirow{3}{*}{$\begin{array}{l}\text { Uji Mann-Whit- } \\
\text { ney }\end{array}$} \\
\hline & \multicolumn{2}{|c|}{ Pretest } & \multicolumn{2}{|c|}{ Posttest } & \multicolumn{2}{|c|}{ Pretest } & \multicolumn{2}{|c|}{ Posttest } & & \\
\hline & $\mathrm{n}$ & $\%$ & $\mathrm{n}$ & $\%$ & $\mathrm{n}$ & & & $\%$ & & \\
\hline \multicolumn{11}{|c|}{ Kualitas Hidup Pasien } \\
\hline Baik & 1 & 2 & 44 & 86,3 & 0 & 0 & 0 & 0 & $\mathrm{p}=0.000$ & $\mathrm{p}=0.000$ \\
\hline Cukup & 4 & 7,8 & 6 & 11,8 & 0 & 0 & 9 & 36 & & \\
\hline Kurang & 46 & 90,2 & 1 & 2 & 25 & 100 & 16 & 64 & & \\
\hline \multicolumn{11}{|c|}{ Gula Darah Puasa } \\
\hline Normal & 0 & 0 & 1 & 2 & 0 & 0 & 0 & 0 & $p=0.000$ & $\mathrm{p}=0.000$ \\
\hline Pre Diabetes & 0 & 0 & 46 & 90,2 & 0 & 0 & 1 & 4 & & \\
\hline DM & 51 & 100 & 4 & 7,8 & 25 & 100 & 24 & 96 & & \\
\hline \multicolumn{11}{|l|}{ Tekanan Sistole } \\
\hline Normal & 22 & 43,1 & 23 & 45,1 & 7 & 28 & 6 & 24 & $\mathrm{p}=0.131$ & $\mathrm{p}=0.203$ \\
\hline Pre Hipertensi & 15 & 29,4 & 18 & 35,3 & 10 & 40 & 14 & 56 & & \\
\hline Hipertensi I & 10 & 19,6 & 9 & 17,6 & 7 & 28 & 5 & 20 & & \\
\hline Hipertensi II & 4 & 7,8 & 1 & 2 & 1 & 4 & 0 & 0 & & \\
\hline \multicolumn{11}{|l|}{ Tekanan Diastole } \\
\hline Normal & 12 & 23,5 & 11 & 21,6 & 10 & 40 & 4 & 16 & $\mathrm{p}=0.539$ & $\mathrm{p}=0.509$ \\
\hline Pre Hipertensi & 11 & 21,6 & 18 & 35,3 & 5 & 20 & 14 & 56 & & \\
\hline Hipertensi I & 27 & 52,9 & 22 & 43,1 & 9 & 36 & 7 & 28 & & \\
\hline Hipertensi II & 1 & 2 & 0 & 0 & 1 & 4 & 0 & 0 & & \\
\hline
\end{tabular}

Hasil Uji Wilcoxon Dan Uji Mann-Whitney pada tabel 2 menunjukan bahwa terdapat perbedaan kualitas hidup pasien DM dan kadar gula darah puasa sebelum dan sesudah diberikan intervensi Co-HELP Modification serta ada perbedaan antara kelompok intervensi dan kelompok kontrol yang hanya mendapat terapi farmakologi dengan menunjukan hasil $\mathrm{p}<$ 0,05 , namun untuk varaibel tekanan sistole dan tekanan distole menunjukan bahwa untuk 
tidak ada perbedaan sebelum dan sesudah intervensi Co-HELP Modification serta tidak ada perbedaan antara kelompok intervensi dan kelompok kontrol.

Tabel 3. Hasil Uji Regresi Logistik Ordinal

\begin{tabular}{|c|c|c|}
\hline Variabel Dependen & Nilai $\mathbf{p}$ & Odds Ratio \\
\hline $\begin{array}{ll}\text { Kualitas } & \text { Hidup }\end{array}$ & 1,000 & 0,0051 \\
\hline \multicolumn{3}{|l|}{ Pasien DM } \\
\hline Gula Darah Puasa & 0,975 & 0,065 \\
\hline Tekanan Sistole & 1,000 & 0,49 \\
\hline Tekanan Diastole & 0,315 & 5,384 \\
\hline
\end{tabular}

Tabel 3. Menunjukkan nilai $\mathrm{p}$ variabel dependen (kualitas hidup pasien DM, gula darah puasa, tekanan sistole dan tekanan diastole) > 0.05 artinya model sudah sesuai/cocok. Kesimpulan dari hasil yang didapat bahwa variabel independen (intervensi Co-HELP Modification, umur, jenis kelamin, lama menderita/sakit DM dan pekerjaan) secara simultan berpengaruh terhadap variabel dependen. Selain itu secara statistik dapat disimpulkan bahwa; (1) responden umur termuda memiliki kecenderungan peningkatan kualitas hidup 0,0051 kali lebih besar dibandingkan dengan responden umur tertua, (2) responden umur termuda memiliki kecenderungan penurunan gula darah puasa 0,065 kali lebih besar dibandingkan dengan responden umur tertua, (3) responden umur termuda memiliki kecenderungan penurunan tekanan sistole 0,49 kali lebih besar dibandingkan dengan responden umur tertua dan (4) responden umur termuda memiliki kecenderungan penurunan tekanan diastole 5,384 kali lebih besar dibandingkan dengan responden umur tertua.

\section{Pembahasan}

Tabel 2, menunjukkan bahwa ada perbedaan kualitas hidup pasien DM sebelum dan sesudah diberikan intervensi pada kelompok intervensi serta ada perbedaan kualitas hidup pasien DM antara kelompok intervensi dan kelompok kontrol yang hanya mendapat terapi farmakologi dengan menunjukkan nilai $\mathrm{p}=0.000$ atau $\mathrm{p}<0.05$.
Pada dasarnya tujuan penatalaksanaan DM secara umum adalah meningkatkan kualitas hidup pasien DM. Kerangka pelaksanaan DM meliputi edukasi, nutrisi yang tepat, aktivitas yang teratur, terapi farmakologi dan monitoring gula darah. ${ }^{4}$ Co-HELP modification merupakan program modifikasi dari program Co-HELP yang dikembangkan pertama kali oleh Ibrahim et.al tahun 2016 dan kemudian program Co-HELP dimodifikasi sesuai dengan budaya dan karakterisitik orang Indonesia khususnya orang Maluku. Co-HELP modification menggabungkan lima kerangka pelaksanaan DM dengan enam sesi pertemuan, pasien diberikan edukasi dan demonstrasi gaya hidup sehat DM,

Edukasi dengan tujuan promosi gaya hidup sehat, perlu selalu dilakukan sebagai bagian dari upaya pencegahan dan merupakan bagian yang sangat penting dalam pengelolaan DM secara holistic. ${ }^{4}$ Pada dasarnya pengetahuan yang baik akan menghasilkan perilaku positif pasien sehingga lebih terbuka dan objektif dalam menerima informasi terkait penatalaksanaan DM,. Keterbukaan pasien DM terhadap informasi kesehatan akan menuntun pasien untuk aktif menjalankan aktivitas self-care, sehingga kadar glukosa darah dapat terkendali dan status kesehatan pasien tetap stabil. ${ }^{7}$ Pada penelitian ini responden sangat aktif melaporkan kemajuan perawatan diri yang sudah dilakukan saat peneliti mengevaluasi pada setiap sesi pertemuan, menurut responden dengan setiap pengetahuan yang di dapat dari Co-HELP modification ada proses perubahan perilaku perawatan diri yang dilakukan untuk mencegah terjadinya komplikasi dan meminimalkan gejala yang timbul sehingga responden lebih menikmati hidup tanpa ada rasa khawatir akan komplikasi dari DM. Hal ini sejalan dengan tujuan teori Self Care Orem yang menyatakan perawatan diri adalah fungsi regulasi manusia bahwa individu harus, dengan pertimbangan, melakukan sendiri atau harus dilakukan bagi mereka untuk mempertahankan hidup, kesehatan, perkembangan dan kesejahteraan. ${ }^{8,16}$ 
Tabel 2, menunjukkan bahwa ada perbedaan kadar gula darah puasa sebelum dan sesudah diberikan intervensi pada kelompok intervensi serta ada perbedaan kadar gula darah puasa antara kelompok intervensi dan kelompok kontrol yang hanya mendapat terapi farmakologi dengan menunjukkan nilai $\mathrm{p}=0.000$ atau $\mathrm{p}<0.05$.

Sampel gula darah puasa diambil saat pasien tidak makan makanan selain minum air selama 8 jam. Sampel darah puasa secara umum mencerminkan kadar glukosa dari produksi hati. Pengukuran kadar gula darah puasa memberikan indikasi paling baik dari keseluruhan homeostasis glukosa dan metode terpilih untuk mendiagnosis DM. ${ }^{9}$ Berbagai studi yang ada menyatakan bahwa pasien DM yang menjaga kadar gula darah rata-rata tetap rendah menunjukan insiden komplikasi mikrovaskuler yang rendah, untuk itu pasien DM direkomendasikan untuk mencapai dan menjaga gula darah serendah mungkin mendekati normal. ${ }^{10}$ Pada dasarnya penatalaksanaan DM yang diutamakan untuk mengatasi status hiperglikemi adalah dengan terapi non farmakologis meliputi perubahan gaya hidup dengan melakukan pengaturan pola makan (terapi gizi medis), meningkatkan aktivitas jasmani dan edukasi yang dilakukan secara terus menerus. ${ }^{11}$ Menurut peneliti edukasi Co-HELP modification yang diberikan mempengaruhi perilaku pola diet responden. Dari hasil wawancara dengan beberapa responden mengatakan sudah mengubah pola makan pasien dengan memilih makanan dengan indeks glikemik rendah seperti sagu, ubi-ubian dan keluarga responden juga turut mendorong pasien melakukan diet indeks glikemik rendah dengan cara mengingatkan atau menyediakan makanan tersebut. Selain itu aktivitas fisik juga berpengaruh terhadap penurunan gula darah puasa, pada aktivitas fisik ada dua kondisi dimana otot tubuh akan menggunakan sejumlah besar glukosa. ${ }^{12,13}$

Tabel 2, menunjukkan bahwa tidak ada perbedaan tekanan sistole dan tekanan diastole sebelum dan sesudah diberikan intervensi pada kelompok intervensi serta tidak ada perbedaan tekanan sistole dan tekanan diastole antara kelompok intervensi dan kelompok kontrol yang 30 hanya mendapat terapi farmakologi dengan menunjukkan nilai $\mathrm{p}>0.05$.

Modifikasi gaya hidup merupakan penatalaksanaan DM yang juga bertujuan untuk menurunkan tekanan darah dan mengurangi komplikasi kardiovaskuler. ${ }^{14}$ Untuk menetralkan tekanan darah materi Co-HELP modification menganjurkan pasien untuk diet rendah natrium dan lemak (natrium 5gr/orang/hari, lemak 67gr/orang/hari) serta pasien diberikan pedometer untuk menstimulus pasien aktivitas fisik salah satunya jalan 10.000 langkah perhari sesuai anjuran germas. Menurut peneliti tidak perbedaan tekanan sistole dan diastole yang signifikan pada penelitian ini disebabkan oleh beberapa faktor antara lain; faktor umur responden yang rata-rata kategori dewasa madya. Hipertensi sering ditemukan pada seseorang sejalan dengan bertambahnya umur, hampir setiap orang mengalami kenaikan tekanan sistole sampai umur 80 tahun dan tekanan diastole terus meningkat sampai umur 55-60 tahun, kemudian berkurang secara perlahan atau menurun drastic. 15

Selain itu faktor diet rendah natrium dan lemak yang masih belum di patuhi oleh responden karena responden masih sering konsumsi daging dan seafood yang tinggi natrium dan lemak. Penelitian ini dilakukan saat musim pesta rakyat. Etnis Maluku termasuk mempunyai kebiasaan pesta rakyat dalam menyambut hari-hari besar keagamaan dalam pengertian kebiasaan mengonsumsi makanan sumber asam lemak jenuh tinggi yaitu lemak hewani, seperti, RW (daging anjing), aneka seafood dan berbagai makanan yang terbuat dari daging babi sehingga berpengaruh pada tekanan darah pasien yang tidak mengalami perubahan secara bermakna. Asupan makanan dengan kandungan lemak dan natrium yang tinggi dapat memengaruhi tinggi rendahnya tekanan darah dalam tubuh sehingga menyebabkan terjadinya hipertensi. Kenaikan kadar natrium dalam darah dapat merangsang sekresi renin dan mengakibatkan penyempitan pembuluh darah perifer yang berdampak pada meningkatnya tekanan darah. ${ }^{12}$ Oleh sebab itu menurut peneliti dampak edukasi terhadap perubahan tekanan darah menjadi normal perlu waktu yang 
$>6$ minggu dan perlu menambah materi terkait manajemen diet rendah natrium. Karena pada penelitian ini materi lebih banyak berfokus pada diet tentang DM.

\section{Kesimpulan}

Simpulan dari penelitian ini adalah Community-Based Healthy Lifestyle Intervention Program (Co-HELP) Modification berpengaruh terhadap peningkatan kualitas hidup, penurunan gula darah puasa, dan penurunan tekanan darah sistole serta tekanan diastole pasien DM di Puskesmas X

\section{Daftar Pustaka}

1. World Heart Federation. Strategi 2018-2020 Because Every Heartbeat Matters, 1-8: 2018

2. International Diabetic Federation. Diabetes ATLAS, $7^{\text {th }}$ Edition. 2015

3. Kemenkes, R. I. "Hasil utama RISKESDAS 2018." Online) http://www. depkes. go. id/resources/download/info-terkini/materi_ra-

korpop_2018/Hasil\% 20Riskesdas 202018 (2018).

4. PERKENI. Pengelolaan dan pencegahan diabetes melitus tipe 2 di indonesia 2015. Jakarta: Pengurus Besar PERKENI: 2015

5. Malini, H,. Copnell, B., \& Moss, C. Consideration In Adopting A Culturally Relevent Diabetes Health Education Pragramme; An Indonesia Example: 2015.

6. Rantung, J., Hubungan Self Care dengan Kualitas Hidup Pasien Diabetes Melitus (DM) di Persatuan Diabetes Indonesia (Persadia) Cabang Cimahi. Bandung; Universitas Advent Indonesia: 2015

7. Javanbakht, M., Abolhasani, F., Mashayekhi, A., Baradaran, H. R., \& Jahangiri, Y. Health Related Quality of Life in Patients with Type 2 Diabetes
Mellitus in Iran : A National Survey, 7(8), 1-9. : 2012

https://doi.org/10.1371/journal.pone.0044526

8. Alligood, M.R Nursing Theorists and Their Work, Eight Edition. Missouir Elseiver Mosby. Singapore: 2014

9. Black, J. M \& Hawks, J. H. Medical Surgical Nursing; Clinical Management For Positive Outcomes. Singapore: Elsevier; 2014

10. Suyono, S., dkk. Penatalaksanaan Diabetes Melitus Terpadu. Jakarta; Universitas Indonesia: 2018

11. Ernawati. Penatalaksanaan Keperawatan Diabetes Melitus Terpadu dengan penerapan Teori Keperawatan Self Care Orem. Jakarta: Mitra Wacana Medika: 2013

12. Guyton, A.C., Hall, J. Medical Physiology 12 edition. Singapore; Elsevier: 2016

13. Utami, T.D., Karim, D., \& Agrina., FaktorFaktor Yang Mempengaruhi Kualitas Hidup Pasien Diabetes Melitus Dengan Ulkus Diabetikum. Riau; Universitas Riau: 2014.

14. Jhonson, H., Documented Lifestyle Education Among Young Adults With Incident Hypertension. Journal Of General Internal Medicine: 2014

15. Andria K.M. Hubungan Antara Perilaku Olaraga, Stress dan Pola Makan Dengan Tingkat Hipertensi Pada Lansia di Posyandu Lansia Kelurahan Gebang Putih, Kecamatan Sukolilo Kota Surabaya; Universitas Airlangga: 2013.

16. Astuti, Astuti, and Agus Purnama. "Pengaruh Membaca Al-Quran terhadap Kadar Glukosa Darah pada Pasien Diabetes Melitus di RSUD Cengkareng Tahun 2018." Jurnal Ilmiah Ilmu Keperawatan Indonesia 9.02 (2019): 577-584. 